\title{
Ontwikkeling van 'n studie-oriëntasievraelys in wiskunde
}

\author{
J.G. Marec* \\ Departement Skoolvoorligting, Universiteit van Pretoria, Pretoria, 0002 \\ W.J. Schocman \\ Departement Sielkunde, Randse Afrikaanse Universiteit, Auckland Park, 2006
}

Ontvang 2I Mei 1997; alanvaar 9 Junie 1997

\section{UITTREKSEL}

Die doel van hierdie studie was on 'n studie-oriëntasievraelys in wisknnde vir alle leerders in Suid-Afrika te standaardiseer: Die' populasie is gedefinieer as alle leerders in Said-Afrika wat wiskunde in graad 8 en 9 neem, asook in graad 10 en 11 . " Gestratifiseerde, ewekansige, tweefase-steckproef is getrek. Statistiese tegnieke het betroubatheidsbepaling, interkorrelasies (ten einde kriteriumverwante geldigheid te bepaal), normbepaling, asook interkorrelasies Itssen faktore ingeshit. Die data is me' belualp van MANOVA, ANOVA en die Scheffétoets ontleed. Die resultate word bespreek en die gevolgtrekking word gemaak dat die braelys 'n nuttige instrument kan wees vir gebraik in wiskundeklaskamers in Suid-Afrika.

\section{Anstract}

\section{Development of a study orientation questionnaire in mathematics}

The aim of this study was to standardize a study orientation questionnaire in mathematics for learners from all language groups in South Africa. The population was defined as all leamers taking mathematics in Grades 8 and 9, and in Grades 10 and 11 in high schools in South Africa. A stratified, random, two stage sample was then drawn. Statistical analyses included determining of reliability, intercorrelations (with a view to establishing criterion-related validity), norm determining and intercorrelations between factors. The data obrained were analysed by means of statistical techniques including MANOVA, ANOVA and the Scheffé test. Results are discussed. It is concluded that the questionnaire could be a useful instrument for use in classrooms in South Africa.

\section{INI.EIDING}

Vanuit 'n didaktiese, asook ' $n$ sielkundige perspektief word baic aandag gegee aan loetsing en evaluering. Die oorkocpelende doel met toetsing is enersyds om te vergelyk en andersyds bied dit aan Ieerders en studente' die geleentheid om hulsell te ontdek.' Owen ${ }^{2}$ gaan verder en beskryl die doel van toetsing as vierledig van aard: die onderrig-, voorligting-, administratiewe, asook die navorsingsdoelstelling.

Leerders se prestasie in wiskunde word gewoonlik in verband gebring met hul kognitiewe potensiaal. In hierdie verband word die resultate van IK- en aanlegtoetse dikwels beskou as maatstaf vir die voorspelling van leerders se tockomstige prestasie in wiskunde. Presteer lecrders nic in ooreenstemming met die verwagtinge wat vir hulle geprojekteer word nic, word daar dikwels verwys na onderprestasic. Dit is vanselisprekend 'n oorvereenvoudigde siening van prestasie en onderprestasic. Talle ander veranderlikes, afgesien van kognitiewe potensiaal (soos gemeet deur gestandaardisecrde intelligensie- en aanlegtoetse), speel 'n rol in leerders se uiteindelike prestasic in enige vak, maar in die besonder in hul prestasie in wiskunde. Hierdie laktore sluit aspekte

\footnotetext{
* Outeur aan wie korrespondensie gerig kan word.

- Vir die doel van hierdie navorsing word die term leerders verder aan gebruik om te verwys na sowel skoolleerlinge, van alle bevolk. ingsgroepe, manlik sowel as vroulik, as sfudente aan tersiêre instansies.

" In hierdie studie word die standpunt gehuldig dat enige rasse- of etniese klassifikasie van 'n bevolkingsgroep 'n kunsmatige manier is om tussen mense te onderskei. Dit herinner boonop aan die taal van die apartheidsera, mar dit is steeds sinvol en nodig om bepaalde onderskeidinge te treften einde die bestann van ongelykhede in SuidAfrikaanse bevolking uit te lig, met die oog op regstelling.

- Die 199.3-syfers is die mees onlangse volledige syfers wat beskikbaar is."
}

soos bekwaamheid, persoonlikheid, belangstelling en leerders se agtergrond, kultuur, asook die gehalte van onderrig in. ${ }^{3}$

\section{PROIBLEEMSTEL.LING}

Die sentrale probleem wat in hierdie artikel bekyk word, is onderprestasie in wiskunde deur Suid-Afrikaanse leerders. Die wiskundepunte wat an leerders toegeken word, bepaal nie slegs of lecrders druip of deurkom nic. Dit het ook 'n invloed op faktore soos moontlike toelating tot universiteitstudic, die verwerwing van beurse en die verkryging van werk. In '" neutedop: dit beïnloed leerders se hele lewe. Dit is dus nie verbasend nie dat daar op nasionale vlak kommer bestaan oor die hoë attrisie- of uitvalsyfer, maar veral oor die vlak van onderprestasie in wiskunde. Die uitslac van die Third international Mathematics and Science Sudy (TIMMS) dui tewens daarop dat Suid-Afrikaanse lecrders die swakste gevaar het van al die 41 lande wat die studic voltooi het." Onderprestasie in wiskunde kom onder alle bevolkingsgroepe ${ }^{h}$ in Suid- Afrika voor. ${ }^{5.6}$ Brodie $^{7}$ spreck dic mening uit dat onderprestasic in wiskunde meisies erger ralak as seuns, en dat swart lecrders heelwat swakker presteer as leerders uit ander bevolkingsgroepe; asook dat laer sosio-ekonomiese stand 'n vername bydraende faktor is tot onderprestasic in wiskunde. Die volgende sylers word ter wille van perspektief verskaf:

Uit tabel 1 blyk dit duidelik dat die slaagpersentasies deurgaans laag is, maar dat swart leerders deurgaans heelwat swakker doen as hul medelecrders uit ander bevolkingsgroepe.

Dit blyk onder meer uit tabel 2 dat dogters uit alle bevolkingsgroepe vecl minder daartoe geneig is om wiskunde tot in gralad 12 te neem as seuns. Hierdic verskil is ongetwyfeld nic (net) aan onderprestasie te wyte nic, soos verder aan in hierdie artikel bespreck sal word. 
Evaluering van leerders se studie-oriëntasie in wiskunde Algesien van ' $n$ verskeidenheid intelligensic-, persoonlikheids-, belangstellings-, prestasic-, aanvangsevaluasie-, verrigtings-, bekwaamheids- en diagnostiese toetse, is daar tans geen toets beskikbaar waarmec lecrders se studie-oriëntasie spesifiek in wiskunde vasgestel kan word nie. Die Raad vir Geesteswetenskaplike Navorsing (RGN) stel dic Opname vir Studiegewoontes en -houdings (OSGH) beskikbaar vir die evaluering van leerders se studie-oriêntasic. Dic OSGH is egter enersyds ontwerp om lecrders se studic-orièntasic in die algemeen te meet. Andersyds is hierdie toets slegs gestandalardiseer vir gebruik deur lecrders in skole van die destydse Departementc Onderwys en Kultuur: Administrasic Volksraad en Raad van Vericenwoordigers.

Die standpunt word in hierdic artikel ingeneem dat leerders se prestasie in wiskunde betekenisvol verbeler kan word indien leerders met 'n ontoereikende studie-oriëntasic in wiskunde gehelp kan word om hul studic-oriëntasie te verbeter. Taljaard en Prinsloo (bl, 420) sê in hierdie verband die volgende van die (OSGH):

Die lae korrelasie met metings van skolastiese annleg en noue verband met akademiese sukses maak die OSGH geskik vir insluiting by ander skale in navorsing oor onderwys.

Met ander woorde, dit is vanuit 'n sielkundige perspekticf nie van deurslaggewende belang dat daar 'n hoë korrelasie tussen die studic-oriëntasievraelys en intelligensic of aanleg gevind sal word nic. Vecl eerder sal bevredigende korrelasie lussen dic beoogde studic-oriëntasicvraclys en akademicse sukses (prestasic in wiskunde) so 'n skaal geskik maak vir insluiting by ander skale oor sielkundige meting in die onderwys.

Verskeic metodes word gebruik vir die evaluering van leerders se studie-oriëntasie in wiskunde. Dit sluit observasie, die onderhoudmelode, die nagaan van skrifte, toetsing en cksaminering in. Daar bestaan klaarblyklik 'n behoefte aan 'n vraelys met gocic psigometriese eienskappe, wat relatief min tyd in beslag sal neem, wat betroubare (gestandaardisecrde) resultate sal lewer en wat maklik op grool groepe lecrders tocgepas sal kan word. Die beoogde studic-oriëntasievraclys is dus saamgestel om enkele aspekte van toetsinterpretasic in wiskunde te bevorder: 10

(i) Die vraclys moet in die eerste plek informasie verskaf oor verskillende aspekle van lecrders se studie-orientasie in wiskunde.

(ii) Noukeurige ontleding van die vraclys behoort sielkundiges" te kan help om insig te bekom oor die redes waarom sekere leerders 'n goeie en ander leerders 'n minder goeie studieoriëntasic in wiskunde openbaar.

(iii) Die vraclys moet 'n geheelbeeld verskaf ten cinde siclkundiges in staat te stel om nic alleen lecrders se studicoriëntasic te evalueer nic, maar ook riglyne daar te stel vir die optimalisering van lecrders se prestasic in wiskunde.

'n Sielkundige toets van hierdie aard behoort daarop ingestel te wees om veral ook ondersoek in te stel na ander aspekte as bloot evaluering van kognitiewe aspekte. Die fokus van hierdie navorsing is dan 'n vername aspek van die problematick van ontoereikende wiskundeprestasie: die wortel van "probleme" setel ook, walarskynlik veral, buite die kognitiewe terrein. Dic belangrikheid van 'n goeie affektiewe onderbou, as noodsaaklike ondersteunende struktuur vir toereikende kognitiewe prestasic in wiskunde, kan byvoorbeeld kwalik oorskat word. Leerders se vlak van emosionele funksionering, hul persoonlikheidsamestelling, motivering, gevoclens rondom wiskunde, dic wyse warop hul onderwysers, die klasatmosfeer, hul huislike omstandighede en die onderrig van die vak beleef; kortom, hul totale studie-oriëntasie in wiskunde, speel 'n betekenisvolle rol in hul cindelike prestasies in hierdie vak.

\footnotetext{
- Die term siclkundiges verwys in hicrdie artikel na sowel sielkundiges as voorligters, onderwysers en dosente.
}

TABEL 1 Slaagpersentasies in wiskunde (Graad 12) per bevolkingsgroep in 1993

\begin{tabular}{|l|c|c|c|c|}
\hline \multirow{2}{*}{ Graad } & \multicolumn{4}{|c|}{ Slaagpersentasies in wiskunde (1993) } \\
\cline { 2 - 5 } Hoër & Swart & Wit & Kleurling & Asiër \\
\cline { 2 - 5 } Standaard & $1,58 \%$ & $17,61 \%$ & $3,30 \%$ & $12,54 \%$ \\
\hline
\end{tabular}

TABEL 2 Verspreiding van Suid-Afrikaanse wiskundeleerders in matriek (1993) per moedertaalsprekende groep

\begin{tabular}{|c|c|c|c|c|c|c|c|c|}
\hline \multirow[b]{3}{*}{$\begin{array}{l}\text { GRAAD/ } \\
\text { TOTAAL }\end{array}$} & \multicolumn{4}{|c|}{$\begin{array}{c}\text { AFRIKATAALSPREKENDES } \\
\text { (wie wiskunde-onderrig in Engels ontvang) }\end{array}$} & \multicolumn{4}{|c|}{$\begin{array}{l}\text { AFRIKAANS- EN } \\
\text { ENGELSSPREKENDES }\end{array}$} \\
\hline & \multicolumn{2}{|c|}{ SEUNS } & \multicolumn{2}{|c|}{ DOGTERS } & \multicolumn{2}{|c|}{ SEUNS } & \multicolumn{2}{|c|}{ DOGTERS } \\
\hline & $N$ & $\%$ & $N$ & $\%$ & $N$ & $\%$ & $\mathrm{~N}$ & $\%$ \\
\hline HG & 36043 & 21,30 & 37573 & 16,60 & 11041 & 32,70 & 9613 & 28,83 \\
\hline SG & 15071 & 8,91 & 18607 & 8,22 & 13039 & 38,61 & 9905 & 29,71 \\
\hline $\begin{array}{l}\text { TOTALE GETAL } \\
\text { (MATRIEK) }\end{array}$ & 169197 & 100 & 226321 & 100 & 33768 & 100 & 33342 & 100 \\
\hline
\end{tabular}




\section{NAVORSINGSONTWERI' EN PROSEDURE}

Literatuurstudie het onder andere die volgende aspekte van studie-oriëntasic in wiskunde uitgelig:

- Leerders openbaar 'n bepaalde studiehouding teenoor wiskunde. Dit sluit aspekte soos die wil om te presteer, motivering" en verwagtinge oor die vak in, en beïnvloed onder andere hul belangstelling in wiskunde. ${ }^{2}$ I licronder ressortecr ook aspekte soos leerders se siening van die self, die aard van wiskunde en dic aard van die leer van wiskunde. ${ }^{13}$

- Lecrders se alfektiewe ingesteldheid beinvloed hul ingesteldheid jeens die vak. 'n Verskynsel soos wiskunde-angs (wat kan manifesteer in die vorm van doellose, herhalende gedrag) sal hul belangstelling na alle walarskynlikheid negaticl beinvloed.

- Leerders se studiegewoontes in wiskunde is onder meer belangrik in terme van die inoefening van belangrike insigte in die vak. Die aan die dag lê van aangeleerde, konsekwente, eflektiewe studiemetodes (insluitende toets- en selftoetsstrategieë), die uilvoering van opdragte in wiskunde, die konsek wente en behoorlike inoefening van basiese konsepte, maak 'n belangrike decl van lecrders se studie-oriëntasic in wiskunde uit. ${ }^{14}$

- Lecrders se problecmoplossingsingesteldheid (wat aspekte soos problecmsentrering, koöperatiewe leer, die implementcring van metakogniticwe Iecrstrategieë, beheer ten opsigte van monitering en besluitneming tydens die proses van problecmoplossing kan insluit) oefen 'n potensieel betekenisvolle invloed uit op hul uiteindelike prestasie in wiskunde. ${ }^{13}$

- Leerders se studiemilicu (sosiale, fisicke én beleefde milieu) vorm ' $n$ integrale deel van hul studic-oriëntasic. Leerders kom immers uit verskillende huise en het verskillende aglergronde. Hulle verskil ten opsigte van etniese en kulturele agtergronde; motivering verskil van kultuur tot kultuur soos ook lecrders se belangstellings en die premie wat hul ouers op prestasic in wiskunde plaas. ${ }^{15}$ Lecrlers uit nie-stimulerende omgewings het dikwels agterstande, openbaar 'n mindere mate van waaghouding en is dikwels stadiger (hocwel nie noodwendig "swakker" nie) leerders as lecrders uit minder beperkte omgewings.

- Leerders glo of dat sukses ol mislukking buite hul beheer lê (eksterne lokus van beheer), of dat hulle beheer uitocfen oor die laktore wat hul sukses of mislukking medebepaal. Die wyse waarop leerders byvoorbeeld hul onderwysers beleef, oefen in alle waarskynlikheid 'n betekenisvolle invloed op hul ingesteldheid jeens die vak uit.

- Die wyse waarop leerders inligting in wiskunde verwerk, medebepaal in 'n betekenisvolle mate hul prestasies in die vak. Inligtingsverwerking sluit kritiese denke, algemene én spesificke verstaan-, leer-, samevatting- en leesstrategieë in. Hierdie strategieë kan gebruik word om probleme in wiskunde op te los en verskaf dikwels 'n malatstaf van die mate waarin leerders wiskunde werklik verstaan.

- Leerders se wiskundige wêreldbeskouing, oor die self, oor die aard van wiskunde en oor die leer van wiskunde; kortom, lecrders se totale studic-oriëntasic in wiskunde, holisties gesien, beïnvloed hul problecmoplossingsvermoë en hul uiteindelike prestasie in die vak. Reynolds en Wahlberg ${ }^{15}$ (bl. 157) benadruk die feit dat daar ' $n$ noue wisselwerking tussen die verskillende aspekte van leerders se studie-oriëntasie bestaan, soos volg:

Explanatory factors operate in a complex network of direct, indirect, and mediating effects .... changing one factor simultaneously affects another:
Die volgende bestande loetse het 'n invloed op die keuse van items en struktuur van die studie-oriëntasievraclys gehad: Dic Opsomming ran Studiegewoontes en - hondings, "' Learning and Sindy' Strategies Imeentory (LASSI) ${ }^{17}$. Motivated Strategiesfor Learning Questionnaire, ${ }^{\text {in }}$ Informele studic-oriëntasicvraelyste in wiskunde' asook Diagnosliese Toelse in wiskundige taal. ${ }^{19} \mathrm{Na}$ annleiding van die voorgemelde literatuurstudie, en met inagneming van die struktuur en items van die toetse hicr aangedui, is vermoed dat die vraelys uit ses velde (studiegewoontes in wiskunde, wiskunde-angs, studichoudings jeens wiskunde, problecmoplossingsgedrag in wiskunde, studiemilieu mel betrekking $10 t$ wiskunde en inligtingsverwerking) kon bestaan. Die items in die vraelys is dus aanvanklik in ses velde ingedeel. Die volgende kriteria is in ag geneem by die skryf van dic items:

- Dic onderrig- en lecrsftuasie in wiskunde, spesilick in SuidAfrika.

- Die innoud van dic items, asook die woorde wat daarin gebruik is, moes op so 'n vlak wees dat dit vir alle toetslinge aanvaarbaar is.

- Sommige van die toetslinge het ontocreikende onderrig in wiskunde ontvang, kom uit nie-stimulerende studie-milieus en ontvang hul wiskunde-onderrig in 'n Iweede taal (Engels). Die stellings in die vraclys het betrekking op hoe individue voel of handel ten opsigte van aspekte van hul prestasies in wiskunde ${ }^{\mathrm{c}}$. Toetslinge word voor verskeie hipotetiese situasies gestel waarin hulle dan tussen verskeic alternatiewe die een moet kies wat met hul gevoel of waarskynlike optrede ooreenstem. Elke stelling moet aan die hand van 'n 5 puntskaal, naamlik byna nooit, soms, dikwels, gewoonlik of byna altyd beantwoord word. Sommige stellings is gunstig ten opsigte van die aspekte gestel en ander nic.

Die hele vraelys is uiteindelik geherstruktureer in die lig van die resultate van die faktor- en itemontleding (wat verder aan bespreck word).

\section{Beoordeling van die items deur kundiges}

Die vraelys is aan 'n komilce van kundiges by die RGN vir dic beoordeling van die stellings voorgelê. By die beoordeling van stellings is daar onder andere gelet op duidelikheid, ecnduidigheid, ondubbelsinnigheid, gebruik van woorde met presiese betekenis en die ekwivalensic van die Afrikaanse en Engelse stellings. Aandag is ook geskenk aan die plasing van die stellings in bepaalde velde. Stellings wat na die oordeel van dic komitec nie verband hou met die veld waarin dit geplaas is nic, is gewysig of onder ' $n$ ander meer toepaslike veld ingedeel. Hierna het die opstellers die vraelys aan vyf wiskundiges verbonde aan universitcite vir kommentaar voorgelê. Die vraelys is na aanleiding van die kommentaar verder aangepas.

\section{Faktor- en itemontleding}

Die voorlopige vraclys het in die geval van graad 8 - en 9-leerders uit 150 stellings bestaan (in die geval van graad 10-en I1-lecrders uit 165 stellings). Vir die faktorontledings om die konstrukgeldigheid van die studie-oriëntasievraelys te bepaal, is beide die SAS-rekenaarstelse ${ }^{20}$ en die BMDP4M-rekenaarprogram ${ }^{21}$ gebruik. Ondersockende faktorontleding het aan die lig gebring dat 3 velde in die geval van graad 8 en 9 onderskei kon word, te wete studiegewoontes ( 38 items), wiskunde-angs

\footnotetext{
- Die volledige vraelys is by navraag heskikbaar.
} 
(28 itcms), cn studiehoudings ( 11 items). In die geval van graad $10 \mathrm{en} 11$ kon 'n vierde veld onderskei word, te wete lokus van beheer ( 13 itcms).

Ten einde die meriete van die finale jiems van die vraclys te bepaal, is itemontleding per veld op die finale 90 ) items (graad 10 en 11) en 77 items (graad 8 en 9) uitgevoer. Vir die doel van hicrdic studic is diskriminasicwaardes hoër as 0,30 (vir die gesamentlike grocpe) as gocie waardes beskou, terwyl diskriminasiewaardes hoër as 0,20 (in die geval van ontledings van die items vir taalgroepe alsonderlik) as gocic waardes beskou is. Uit die data het dit duidelik geblyk dat al die finale items in die vraclys

- minstens vir elk van die drie taalgroepe 0,20 of hoër met dic totaaltelling van elke veld se items korrelecr; en

- minstens 0,30 of hoër (geringe variasie word toegelaat) met dic totalaltelling van die items van elke veld vir die drie groepe saam korrelecr.

Toetsing van die vraelys op 'n groepie toetslinge

Dic vraelys is eerstens op 'n groep van 60 graad 8 -lecrders in 'n swart skool toegepas om moontlike onduidelike aanwysings en items aan die lig te bring. Toetslinge is versock om die nommers van items wat hulle nic verstaan het nic, te omkring en om sinsnedes en woorde wat hulle nie verstaan het nie, te onderstreep. Op grond van die toetslinge se reaksies ten opsigte van die items is die formulering van 'n aantal items verder gewysig/vercenvoudig.

'Toepassing van die voorlopige vraelys vir itemontleding en -seleksie

Die vraclys is deur sielkundiges van die onderwysdepartemente en voorligteronderwysers aan die hand van standaardaanwysings toegepas. Dic voorlopige vraclys is by meeste skole gedurende Augustus en September 1994 toegepas. By sekere skole het die toetsing egter eers tecn die einde van die eerste kwartaal van 1995 plaasgevind. Die toctsafnemers was ook vir die trek van die steekproewe by die skole verantwoordelik. Aanwysings is aan die toetsafnemers verskaf om die verlangde aantal lecrders te kies.

\section{Beplanning en trek van die steekproewe}

Vir die doel van hierdie ondersock is die populasie gedefinieer as alle leerders wat wiskunde in graad $8 \mathrm{en} 9$ neem, asook in graad 10 en 11 , in openbare hoërskole van die destydse onderwysdepartemente van Gazankulu, KwaZulu, Lebowa, Venda, Bophuthatswana, Transkei, Ciskei, die Raad van Verteen- woordigers, Raad van Afgevaardigdes, dic Volksraad en dic Departement van Onderwys en Opleiding. Dic steckprocwe is beplan aan die hand van dic RGN se onderwysdatabasis vir 1991. Die databasis is saamgestel uil gegewens wat die destydse onderwysdepartemente aan die RGN verskaf het. Die gegewens bestaan uit die name van skole met hul beheer, inskrywings vir wiskunde, medium van onderrig, ensovoorts. Ten einde te verseker dat elke belangrike deel van die populasie toereikend in die steckproef verteenwoordig is, is die populasic ecrs in strata of deelpopulasies verdecl. Die volgende strata is in ag geneem: beheer (onderwysdepartemente), medium van onderrig (Afrikaans/Engels) en gebied (stad/platteland). Terwille van bondigheid, en vir die doel van hierdie artikel, word die frekwensies in terme van moedertaalverspreiding verskal. Vir meer besonderhede word die geïnteresseerde leser verwys na die handleiding vir die onderhawige toets, verkrygbaar by die Raad vir Geesteswetenskaplike Navorsing. (Post-hocvergelykings - in die onderhawige geval die Scheffétoets, wat verder aan bespreek word - word uitgevoer om die invloed van twecdetaalonderrig in wiskunde in die Suid-Alrikaanse situasic te probeer peil.)

\section{TABEL 3 Frekwensies}

\begin{tabular}{|l|l|l|}
\hline Taal- en graadgroep & Frekwensie & $\%$ \\
\hline 8/9 Afr. & 494 & 16,4 \\
\hline 8/9 Eng. & 231 & 7,7 \\
\hline 8/9 Afrikatale & 1016 & 33,7 \\
\hline Totaal graad 8/9 & 1741 & 57,8 \\
\hline 10/11 Afr. & 393 & 13 \\
\hline 10/11 Eng. & 418 & 13,9 \\
\hline 10/11 Afrikatale & 461 & 15,3 \\
\hline Totaal graad 10/11 & 1272 & 42,2 \\
\hline & 3013 & 100 \\
\hline
\end{tabular}

Betroubaarhede

Taalgroepe afsonderlik

Die betroubaarheid van die aangepaste velde is met Cronbach se alpha-koëffisiënt bepaal. Terwille van bondigheid word slegs die betroubaarhede vir dic taalgroepe afsonderlik hier weergegee.

TABEL 4 Betroubaarheidskoëffisiënte $\left(r_{t \prime}\right)$ vir die verskillende velde vir graad 8 en 9 , asook graad 10 en 11 , gesamentlik, volgens taalgroepe

\begin{tabular}{|c|c|c|c|c|c|c|}
\hline \multirow{2}{*}{ Velde } & \multicolumn{3}{|c|}{ Graad 8 en 9 $(\mathrm{N}=1741)$} & \multicolumn{3}{c|}{ Graad 10 en 11 (N=1262) } \\
\cline { 2 - 7 } & $\begin{array}{c}\text { Afrikatale } \\
(\mathrm{N}=1016)\end{array}$ & $\begin{array}{c}\text { Engels } \\
(\mathrm{N}=231)\end{array}$ & $\begin{array}{c}\text { Afrikaans } \\
(\mathrm{N}=493)\end{array}$ & $\begin{array}{c}\text { Afrikatale } \\
(\mathrm{N}=451)\end{array}$ & $\begin{array}{c}\text { Engels } \\
(\mathrm{N}=418)\end{array}$ & $\begin{array}{c}\text { Afrikaans } \\
(\mathrm{N}=393)\end{array}$ \\
\hline 1 & 0,900 & 0,934 & 0,940 & 0,887 & 0,931 & 0,933 \\
\hline 2 & 0,866 & 0,901 & 0,923 & 0,851 & 0,905 & 0,921 \\
\hline 3 & 0,793 & 0,861 & 0,832 & 0,712 & 0,879 & 0,857 \\
\hline 4 & & & & 0,623 & 0,783 & 0,676 \\
\hline Totaal & 0,919 & 0,943 & 0,952 & 0,907 & 0,947 & 0,951 \\
\hline
\end{tabular}


Die mecste betroubaarheidskoëflisiënte is in die orde van 0,70 tol 0,90 . Vir dic vraclys as ' $n$ geheel varieer die betroubaarheidskoëflisiënte van 0,623 tol 0,952 . Dic betroubararheidskoëffisiënte kan as hoogs bevredigend beskou word vir die docl walrvoor die vraclys gebruik sal word.

\section{Itemsydigheid}

Analise van dic vraclys se toetsbetroubaarhede openbaar bevredigende ooreenslemming in toetsbetroubaarhede, asook laktoriale soortgelykheid (hier is nie werklik sprake van itemmocilikheidswaardes nic), om welke rede dil wil voorkom asof konstruksydigheid nie in hierdic geval 'n betekenisvolle probleem is nic. In die geval van dic onderhawige vraclys moes sydigheid in items ten opsigte van taal, geslag, ras en sosio-ckonomiese milieu so ver moontlik beperk word. Die standpunt is gehuldig dat die blote feit dat gemiddelde toetstellings op 'n toets vir twee of meer groepe verskil, nie noodwendig dui op sydigheid van die toets ten opsigte van die veranderlike waarmee dic groepe gevorm word nic. Sydigheid ten opsigte van taal, geslag en opvoedkundige vlak is beperk deur oordeelkundige itemseleksic. (Dic aangeleentheid van kulturele sydigheid is vansellsprekend egter tc kompleks om deur itemseleksic alleen vermy te word.)

\section{Normberekening}

Uit 'n noukeurige analise van die diskriminasiewaardes van die finale items wil dit voorkom of nie een van die gekose items een bevolkingsgroep noemenswaardig bo 'n ander groep bevoordeel nie, of geeneen van die waargenome groepverskille in toetsgemiddeldes betekenisvol anders is as wat sielkundiges sou verwag nie en of geeneen van die gekose items deur een bevolkingsgroep radikaal anders as deur' 'n ander bevolkingsgroep verstaan word nie.

Vir hierdie vraelys word van persenticlrange as normpunte gebruik gemaak. Een stel norms word dus verskal vir leerders in graad 8 en 9 enersyds en vir leerders in graad 10 en 11 andersyds. Omdat die steekproef vir dic graad 8- en 9-Icerders alle graad 8en 9-leerders op hoërskool verteenwoordig, en die stcekprocf vir die graad 10-en 11 -lecrders slegs lecrders wat wiskunde in hierdie grade neem, verteenwoordig, is alsonderlike norms vir die twee graadgroepe bepaal. Norms word vir die verskillende velde afsonderlik en vir dic totale vraelys voorsien. Die verskille wat tussen die gemiddeldes van verskillende subpopulasies gevind is. was in die reěl baic klein en kon gewoonlik aan die hand van omgewingsveranderlikes verklaar word.

\section{Gemiddeldes en standaardafwykings}

Gemiddeldes vir graad 8 en 9 , en $10 \mathrm{en} 11$, afsonderlik

TABEL 5 Gemiddeldes $(X)$ en standaardafwykings (S) vir graadgroepe $8 / 9$ en 10/11 afsonderlik

\begin{tabular}{|c|c|c|c|c|}
\hline Velde & \multicolumn{2}{|c|}{$\begin{array}{c}\text { Graad 8/9 } \\
(N=1741)\end{array}$} & \multicolumn{2}{c|}{$\begin{array}{c}\text { Graad 10/11 } \\
(N=1272)\end{array}$} \\
\hline & $\bar{X}$ & $\mathrm{~s}$ & $\mathrm{X}$ & $\mathrm{s}$ \\
\hline 1 & 81,92 & 25,87 & 82,15 & 25,46 \\
\hline 2 & $72,53^{\star}$ & 18,23 & 79,29 & 16,62 \\
\hline 3 & $26,94^{\star}$ & 9,21 & 28,85 & 8,88 \\
\hline 4 & & & 39,42 & 7,41 \\
\hline
\end{tabular}

Statisties betekenisvol op die 5\%-peil
Die statistiese betekenisvolheid van die verskille lussen subgroepe is deurgaans aan die hand van MANOVA en ANOVA bepaal. Waar F-waardes beickenisvol verskil het op die 5\%peil, is Scheffé se metode van paarsgewyse vergelyking ${ }^{22}$ gebruik ten einde te bepaal watter subgroepe statisties betekenisvol van mekaar verskil.

Gemiddeldes vir geslagte alsonderlik

Tabel 6 Gemiddelde (X) en standaardafwykings (s) vir geslags- en graadgroepe afsonderlik

\begin{tabular}{|c|c|c|c|c|}
\hline \multirow[t]{3}{*}{ Velde' } & \multicolumn{4}{|c|}{ Graad 8 en 9} \\
\hline & \multicolumn{2}{|c|}{ Meisies $(N=931)$} & \multicolumn{2}{|c|}{ Seuns $(N=798)$} \\
\hline & X & $\mathbf{s}$ & 8 & $\mathbf{s}$ \\
\hline 1 & 82,39 & 25,90 & 81,31 & 25,79 \\
\hline 2 & $71,36^{\star}$ & 18,53 & 73,85 & 17,73 \\
\hline 3 & $26,32^{*}$ & 9,36 & 27,67 & 8,966 \\
\hline \multirow[t]{4}{*}{ Totaal } & 180,07 & 41,89 & 182,84 & 40,35 \\
\hline & \multicolumn{4}{|c|}{ Graad 10 en 11} \\
\hline & \multicolumn{2}{|c|}{ Meisies ( $N=648$ ) } & \multicolumn{2}{|c|}{ Seuns $(N=607)$} \\
\hline & X & s & 8 & $s$ \\
\hline 1 & $84,50^{\star}$ & 24,09 & 79,56 & 26,60 \\
\hline 2 & $79,67^{\star}$ & 16,10 & 78,88 & 17,16 \\
\hline 3 & $28,15^{\star}$ & 8,91 & 29,59 & 8,78 \\
\hline 4 & $40,10^{*}$ & 7,29 & 38,71 & 7,47 \\
\hline Totaal & 232,42 & 41,10 & 226,74 & 44,87 \\
\hline
\end{tabular}

*: Statisties betekenisvol op die $5 \%$-peil

Kriteriumverwante geldigheid

Samevallende geldigheid: Pearsonkorreiasies

TABEL 7 Pearsonkorrelasies van velde met gestandaardiseerde wiskundetoetse vir graad 9leerders (Gesamentlik, N = 1072)

\begin{tabular}{|l|c|l|l|l|}
\hline $\begin{array}{l}\text { Velde } \rightarrow \\
\text { Toetse } \downarrow\end{array}$ & Gewoontes & Angs & Houdings & Totaal \\
\hline $\begin{array}{l}\text { Wiskunde: } \\
\text { Graad 9 } \\
(\mathrm{N}=472)\end{array}$ & $0,13^{\star \star}$ & $0,46^{\star *}$ & $0,32^{\star \star}$ & $0,36^{\star *}$ \\
\hline $\begin{array}{l}\text { Diagnostiese } \\
\text { toetse in } \\
\text { Wiskundige } \\
\text { taal (N = 470) }\end{array}$ & 0,10 & $0,45^{\star \star}$ & $0,33^{\star \star}$ & $0,33^{\star *}$ \\
\hline
\end{tabular}

**: Statisties betekenisvol op die $1 \%$-peil

\footnotetext{
Veld I: Studiegewoontes (SG/SH) in wiskunde

Veld 2: Wiskunde-angs (WA-MA)

Veld 3: Studiehoudings (SH/SA) in wiskunde

Veld 4: Lokus van Beheer (LB/LC) in wiskunde
} 
Interkorrelasies tussen dic velde

Dic interkorrelasies van die velde vir graad 8- en 9-lecrders en vir graad 10-en II-lecrders word in labelle $8 \mathrm{col} 9$ respekticwelik aangedui.

TABEL 8 Interkorrelasies van die velde vir graad 8en 9-leerders gesamentlik $(\mathrm{N}=1741)$

\begin{tabular}{|c|c|c|c|}
\hline Velde & 1 & 2 & 3 \\
\hline 1 & & & \\
\hline 2 & 0,266 & & \\
\hline 3 & 0,612 & 0,286 & \\
\hline
\end{tabular}

Aangesien die items van elke veld opgestel is om 'n bepaalde faset of aspek van studie-orientasie in wiskunde te meet, behoort die korrelasies tussen die verskillende velde oor die algemeen laag te wees. Uit tabel 8 blyk dat daar'n matige tot hoë verband tussen Velde I en 3 voorkom. Dit is te wagte, aangesien studiehoudings gewoonlik uitmond in bepaalde studiegewoontes, en studiegewoontes dikwels aanduidend is van bepaalde gesindhede jeens wiskunde.

TABEL 9 Interkorrelasies van die velde vir graad 10en 11-leerders gesamentlik ( $N=1262$ )

\begin{tabular}{|c|c|c|c|c|}
\hline Velde & 1 & 2 & 3 & 4 \\
\hline 1 & & & & \\
\hline 2 & 0,410 & & & \\
\hline 3 & 0,571 & 0,299 & & \\
\hline 4 & 0,107 & 0,245 & 0,212 & \\
\hline
\end{tabular}

Uit tabel 9 blyk dit dat die interkorrelasies van die velde vir graad 10-en 11 -leerders dieselfde tendens toon as dié vir graad 8- en 9-leerders. Die interkorrelasies vir Velde 1 en 3 korreleer weereens relatief hoog. Die korrclasiekoëffisiënte dui wel daarop dat die velde 'n gemeenskaplike onderliggende faktor meet. 'n Deeglike ondersoek van die uitslae het aangetoon dat daar nie items is wat hoër korreleer met enige ander veld as met die veld waarin dit opgeneem is nie.

\section{BESPREKING}

Die statisties betekenisvolle korrelasie wat deurgaans gevind is tussen die velde Gewoontes, Angs, Houdings, asook Totaaltelling en prestasie in die kriteriumtoetse wat gebruik is, te wete die Prestasietoets in Wiskunde standerd 7, asook die Diagnostiese Toetse in wiskundige taal, dui waarskynlik daarop dat leerders se prestasie in wiskunde betekenisvol verbeter kan word wanneer aspekte van hul studie-oriëntasie in wiskunde (soos motivering, houding en die afwesigheid van angs in die wiskundeklas) verbeter.

\section{Vergelykings tussen die geslagsgroepe}

Wat geslag betref, is daar in die onderhawige studie statisties betekenisvolle verskille gevind ten opsigte van die velde Angs en Houdings. Seuns in graad 8 en 9 openbaar laer angsvlakke in wiskunde en openbaar ' $n$ beter studiehouding jeens wiskunde as meisies. Hierdie bevinding korreleer met dié van Visser ${ }^{21}$ (bl. 213), wat bevind dat

the atritudes of females become more negative in the period between Sid 5 and Sid 7. They become more anxious about their mathematics studies... Their interest in the subject wanes.

Mwamwenda ${ }^{34}$ spreek in hierdie verband die mening uit dat akademiese onderprestasie deur meisies in die algemeen onder meer daaraan toegeskryf kan word dat meisies meer geneig is tot toetsangs as seuns. Sibaya en Sibaya ${ }^{25}$ wys daarop dat dogters in sekere omstandighede as skaam, teruggetrokke en.minder bedrewe in terme van sosiale interaksies as seuns beskou word, en dat dic vrae wat in wiskunde aan seuns gevra word, gevolglik dikwels van 'n hoër orde is, terwyl vrae op 'n laer kognitiewe vlak aan dogters gevra word. Relaticl' groot getalle meisies uit al dic moedertaalgroepe los wiskunde aan die cinde van graad $9^{8}$, om 'n verskeidenheid redes. Diegene wat wel die vak in graad 10 en 1 I necm, het klaarblyklik laer wiskunde-angsvlakke, openbaar beter studichoudings jeens wiskunde en lê meer optimale studiegewoontes in wiskunde aan die dag; kortom, meisies in graad 10 en 11 openbaar 'n meer positicwe studieoriëntasie in wiskunde as hul manlike eweknieč.

\section{Vergelykings tussen die graadgroepe}

Leerders in graad $10 \mathrm{en} 11$ openbaar betekenisvol laer angsvlakke as hul medeleerders in graad $8 \mathrm{en} 9$. Dit is verstaanbaar, aangesien talle leerders wat "bang" is vir die vak en/of swak in wiskunde presteer, aan die einde van graad 9 die vak los. Ander moontlike verklarings vir die verskynsel is die feit dat leerders in graad 10 en 11 op ' $n$ meer formele denkvlak begin beweeg en derhalwe ' $n$ meer gedistansieerde houding teenoor probleme rondom wiskunde kan inneem, hoe gering ook al. Dit is betekenisvol dat die veld Lokus van Beheer eers by leerders in graad $10 \mathrm{en} 11$ geidentifiseer kon word. Een van die redes vir die verskynsel is waarskynlik dic feit dat leerders in graad $8 \mathrm{en} 9$ verplig word om wiskunde op skool te neem. Eers in grade 10,11 en 12 kan leerders self besluit (weliswaar met begeleiding van betekenisvolle ander) of hulle die vak wil neem of los. Met ander woorde, leerders ervaar in grade 10,11 en 12 dit vir die eerste keer dat hulle beheer kan uitoefen oor die situasie in wiskunde. Piaget ${ }^{26}$ het verklaar dat adolessensie die tydperk is waartydens kinders by uitstek beweeg na 'n fase wanneer hulle veral meer in staat word om formele denkoperasies uit te voer. Sy siening dat leerders reeds op die ouderdom van 12/13 jaar die formeel-operasionele denkstadium betree, is egter reeds deur etlike navorsers as optimisties beskou. ${ }^{27}$ Dit wil eerder voorkom of leerders in die algemeen eers later hierdie denkstadium betree, afhangende van etlike faktore, insluitende hul sosio-ekonomiese status, kulturele milieu en die mate waarin hul ouers hulle ondersteun.

\section{GEVOLGTREKKING}

Die studie-oriëntasievraelys in wiskunde (die SOW), waarvan die ontwerp en standaardisering in hierdie artikel beskryf word, kan moontlik ' $n$ betekenisvolle rol speel in die fasilitering van die volgende aspekte van leerpotensiaaloptimalisering in wiskunde:

(i) As 'n diagnostiese toets. Die SOW kan aan die begin van die akademiese jaar op leerders toegepas word, óf individueel of in groepsverband. Leerders se tellings kan dan nagegaan word om diegene wat hulp, steun, remediëring en raadgewing nodig het, uit te ken. 
(ii) Terapie. Die SOW verskaf aan sielkundiges 'n gestandaardiseerde middel om 'n aantal belangrike agtergrondsgegewens, gevoclens, houdings, gewoontes en gebruike betreffende leerders se akademiese oriëntasie in wiskunde sistematies te ontleed. 'n Profiel van leerders se wiskundeoriëntasie kan maklik saamgestel word. Interpretasie van leerders se response op die vraclys en analise van tekortkominge wat potensieel aanleiding tot swak prestasic kan gee, kan gemaak word.

(iii) Studieriglyne in wiskunde. Die SOW kan aangewend word as 'n middel om sekere basiese beginsels van doeltreffende studic in wiskunde, asook die betekenisvolle rol wat studicomstandighede, insluitende motiverings- en agtergrondsfaktore in akademiese sukses speel, by leerders tuis te bring.

(iv) Navorsing. Dic bevredigende korrelasie met prestasie- en diagnostiese toetse in wiskunde maak die SOW' 'n geskikle mectinstrument vir insluiting by ander skale in navorsing oor die sielkunde. Dit korreleer verder hoog genoeg met prestasie- en diagnostiese toetse in wiskunde om die alleiding te regverdig dat die gebruik van hierdic vraclys kan bydra tot die diagnosering van laktore wat prestasie in wiskunde inhibecr.

(v) Analise van gevoelens, gebruike en houdings as aspekle van leerders se akademiese werk. Dic SOW voorsien sielkundiges van 'n gestandaardisecrde toets om belangrike gevoelens, gebruike en houdings as aspekte van lecrders se akademiese disposisie mee te analiseer. Die toets is primêr ontwerp vir gebruik in wiskunde, malar dit het wyer betekenis in die sin dat verbetering in leerders se prestasie in wiskunde potensieel kan lei tot die optimalisering van aspekte soos lecrders se selfbeeld, asook hul prestasic in verwante vakke (waar insig in basiese wiskundige beginsels 'n voorwaarde is vir oplimale prestasic). Ontleding van daardie gevalle waar leerders se antwoorde betekenisvol verskil van antwoorde wat gewoonlik deur goeie presteerders in wiskunde gegee word, kan van groot nut wees. Sielkundiges kan hiermee gehelp word om aspekle van die verskillende velde van die SOW ten aansien waarvan 'n leerder se prestasie ongunstig is, te gebruik by hulpverlening aan so 'n leerder.

Ten slotte word dit beklemtoon dat prakliese stappe gedoen behoort te word om leerders van alle taalgroepe, maar by uitstek A rrikataalsprekende lecrders se graad van milieubenadecldheid te oorbrug, insluitende hantering van negatiewe onderrig- en leerfaktore wat tans hul wiskundeprestasie ernstig inhibecr (en waaroor daar al tot herhaling geskryf is). Die instelling van uitkomsgebaseerde onderrig behoort hand aan hand te gaan met die inwerkingstelling van sodanige stappe.

\section{BEDANKINGS}

Dank word betuig aan:

a. die RGN vir linansiële hulp tydens die standaardisering van dic SOM;

b. dr. N. Claassen en mnr. W. Prinsloo van die RGN vir hulp tydens die aanvanklike standaardisering van die vraclys; $\mathrm{en}$

c. mev. R. Owen (Universitcil van Pretoria) vir haar hulp met die dataverwerking in hierdie arlikel.

\section{SumMary}

In this study, the design and evaluation of a study orientation questionnaire in mathematics (the SOM) for use by all learners in South Africa, is described.
The high lailure rate in mathematics, at school level as well as at tertiary level, remains a cause for concern. ${ }^{29}$ It is also known that pupils with an apparently high intellectual ability or aptitude for mathematics sometimes underachieve in the subject, whereas some pupils with an apparently low gencral ability or low aptitude for mathematics achieve well in the subject. Furthermore, achievement in school mathematics appears to be one of the best predictors of success at tertiary level. ${ }^{2 .}$ Any attempt to explain the aforementioned phenomenon, as well as to guide pupils towards better achievement in mathematics, will have to take the study orientation of pupils into account. Many pupils who study mathematics display a negative study attitude towards mathematics, which in turn has a potentially negalive bearing on achicvement in mathematics. ${ }^{\text {11.23.2x }}$

The main thrust for this study was the apparent need for a study orientation questionnaire in mathematics. The questionnaire method of assessing pupils' study orientation in mathematics is rarely used and no such standardized test is currently widely used in mathematics classrooms in South Africa.

MANOVA.ANOVA and the Scheflé test were used to determine whether the statistical differences between the means for certain groups were meaninglul. Three and four factors (in the case of Grade 8 and 9 and Grade 10 and 11 pupils respectively) were identilied. Satisfactory reliability coefficients were also established for the test. In some instances, relatively high intercorrelations were found in most instances, confirming the existence of a common underlying factor. Lastly, significantly positive correlations with two criterion tests (the Diagnostic Test in Mathematical Language, as well as the Achievement Test in Mathematics standard 7) were established. Girls in Grade 8 and 9 displayed a more favourable study orientation than boys, whilst it became clear that learners' anxiety levels tended to drop in Grade 10 and 11. Alrican language speaking learners in Grade 10 and 11 in particular gave evidence of a pervasive feeling that they had very little control over adverse circumstances which impact negatively on their achievement in mathematics; inter alia because they are laught in a 'foreign' language.

\section{LITERATUURVERWYSINGS}

I. Oosthuizen, W.L., Maree, J.G. (1993). Evaluering en die leerling. In Klaskamerpraktyk '" inleidende oriëntering, Louw, W.J. red. (Academica, Pretoria) p. 163-171.

2. Owen, K. (1995). Toetssydigheid en toetsbillikheid. In Handleiding vir die gebruik van Sielkundige en Skolastiese metse van die RGN. Owen, K, Taljaard, J.J. reds. (Raad vir Geesteswetenskaplike navorsing, Pretoria), p. 19-84

3. Boyd, R. (1990). Academically talented underachicvers at the end of high school, Giffed Education Imermatiomal, 7, 23-26.

4. Howic, S.J. (1996). The Third International Mathematics and Science study (TIMMS) (Human Sciences Rescarch Conncil, Pretoria).

5. Christic, C. (1991). What ought pre-service teachers to learn in the mathematics chassroom at a College of Education? Paper presented at a Convention of Mathematics Educators. Universily of the Witwaterstand.

6. Blankley, W. (1994). The abyss in african school education in South Africa, South African Journal of Science, 90, 54.

7. Brodic, K. (1994). Political dimensioms of mathematics education: curriculum reconstruction for society in transition-towards action (Association for Mathematics Education of South Africa (AMESA). Claremont)

8. Strauss, J.P. (1997). Inligting verskaf atan J.G. Marec tydens 'n persoonlike gesprek gedurende 1997.

9. Taljaard, J.J., Prinsloo, W.B.J. (1995). Persoonlikheidstoetse. In Handleiding vir die gebruik van sielkundige en skolastiese toetse van die RGN, Owen K., Taljaard J.J. reds. (Penrose Boekdrukkers, 
Pretoria) p. $375-426$.

10. Madge, E.M. \& Van der Walt, H.S. (1995). Interpretasie en gebruike van sielkundige toetse. In Handleiding vir die gebruik van sielkundige en skolastiese toetse van die RGN. Owen, K., Taljaard, J.J. reds. (Penrose Boekdrukkers, Pretoria) p. I.3।- $\mid 48$.

11. Corno, L. (1992). Encouraging students to take responsibility for learning and performance, The Elementary School Journal, 93(1), 69-83.

12. Stewart, J.A. (1991), Why don't girls study mathematics and physical science?, The Australian Science Teachers Journal, 37(3), 18-23

13. Schoenfeld, A.H. (1 985). Mathematical problem solving (Academic Press, New York).

14. Pintrich, P.R., Johnson, G.R. (1990). Assessing and improving students' learning strategies, New Directions for Teaching and Learning, 42, 83-92.

15. Reynolds, A.J., Wahlberg, H.J. (1992). A structural model of high school mathematics outcomes, Journal of Educational Research, $85(3), 150-158$

16. Du Toit, L.B.H. (198I), Handleiding vir die Opmame van Studiegewoomes en - houdings (Raad vir Geesteswetenskaplike navorsing, Pretoria).

17. Weinstein, C.E., Palmer, D.R., Schulte, A.C. (1987). LASSI: Learning and Study Strategies Inventory (H \& H Publishing. Clearwater).

18. Pintrich, P.R., Smith, D.A., Garcia, T., McKeachie, W.J. (199I). A manual for the use of the motivated strategies for learning questionnaire (MSLQ) (NCRIPTAL, The University of Michigan, Ann Arbor).
19. Barnard, J.J. (1990). Diagnostiese toetse in wiskumdige taal (Raad vir Geesteswetenskaplike Navorsing. Pretoria).

20. SAS Institute. (1990). SAS/STAT user's gutide. Version o /GLM THROUGH VARCOMP PROCEDURES] (SAS Institute, Raleigh).

21. Dixon, W.J. (Chief Editor), Brown, M.B., Engelman, L., Jennrich. R.I. (1993). BMDP statistical software: 1983 printing with editions (University of California Press, Berkeley)

22. Steyn, A.G.W., Smit, C.F., Du Toit, S.H.C.. Strasheim, C. (1995). Moderne statistiek vir die praktyk (Pretoria, J.L. van Schaik).

23. Visser, D. (1989). Mathematics - the critical occupational filter for women, Soull African Journal of Science, 85(4), 212-214.

24. Mwamwenda, T.S. (1994). Gender differences in scores on test anxiety and academic achievement among South African university graduate students, Soull African Journal of Psychology, 24, 228230.

25. Sibaya, P.T., Sibaya, D.C. (1997). Pupils' performance on a teachermade mathematics test: the interaction effects of sex, class and stream with age as a covariate, South African Journal of Psychology, 27(1), 9-16.

26. Piaget, J. (1976). Piagcl's theory. In Piaget and his school. Inhelder, B., Chipman, H. eds. (Springer-Verslag, New York).

27. Copeland, R.W. (1984). How children learn mathemarics (MacMillan Publishing Company, New York).

28. Wong, N. (1992). The relationship among mathematics achievement, affective variables and home background, Mathematics Education Research Journal, 4(3), 32-42. 